\title{
Tools for near-atomic resolution in single-particle cryogenic electron microscopy
}

Citation for published version (APA):

Afanayev, P. V. (2016). Tools for near-atomic resolution in single-particle cryogenic electron microscopy. [Doctoral Thesis, Maastricht University]. https://doi.org/10.26481/dis.20160421pa

Document status and date:

Published: 01/01/2016

DOI:

10.26481/dis.20160421pa

Document Version:

Publisher's PDF, also known as Version of record

\section{Please check the document version of this publication:}

- A submitted manuscript is the version of the article upon submission and before peer-review. There can be important differences between the submitted version and the official published version of record.

People interested in the research are advised to contact the author for the final version of the publication, or visit the DOI to the publisher's website.

- The final author version and the galley proof are versions of the publication after peer review.

- The final published version features the final layout of the paper including the volume, issue and page numbers.

Link to publication

\footnotetext{
General rights rights.

- You may freely distribute the URL identifying the publication in the public portal. please follow below link for the End User Agreement:

www.umlib.nl/taverne-license

Take down policy

If you believe that this document breaches copyright please contact us at:

repository@maastrichtuniversity.nl

providing details and we will investigate your claim.
}

Copyright and moral rights for the publications made accessible in the public portal are retained by the authors and/or other copyright owners and it is a condition of accessing publications that users recognise and abide by the legal requirements associated with these

- Users may download and print one copy of any publication from the public portal for the purpose of private study or research.

- You may not further distribute the material or use it for any profit-making activity or commercial gain

If the publication is distributed under the terms of Article $25 \mathrm{fa}$ of the Dutch Copyright Act, indicated by the "Taverne" license above, 


\section{CHAPTER}

SUMMARIZING DISCUSSION 
Introduction of the new generation of direct electron detectors, automatic data collection and development of the new cryo-EM methodology in the last decades, allowed solving structures of various protein complexes with near-atomic resolution. The new detectors, operating in movie-mode (collecting several movie frames during the overall exposure), require new accurate methodologies for automatic processing of the large datasets. We developed, tested and demonstrated a broad spectrum of new approaches for modern cryo-EM data analysis. Our developments, based on the philosophy of reference-free image processing, comprise a robust, fast and effective strategy for the analysis of large single-particle cryo-EM datasets.

In Chapter 1 we introduced the concepts of single-particle cryo-EM, and emphasized its role in the field of structural biology. In our historical overview of technological and methodological developments, we outlined important milestones starting from the design of electron microscope by Ernst Ruska and Max Knoll, and ending with remarkable examples of the recently solved protein structures at near-atomic resolution. Among the methodological developments, we primarily covered pioneering and fundamental works in the field, which today are routinely used in data collection and image processing. We listed the main factors limiting the attainable resolution in cryo-EM and emphasized the methodological issues, investigated in this thesis. Thanks to the instrumentational developments and the computational power now available, we could elaborate on the original ideas (some already 20-40 years old) to improve single-particle cryo-EM analysis.

Chapter 2 illustrates the fundamental advantages of working with large datasets. We showed, that a cryo-EM dataset itself already contains statistically important information, which can be used retrospectively to improve the quality of the data. One can thus remove the fixed pattern from each digitally recorded image. In movie-mode cryo-EM data this fixed-pattern background hampers the movie alignments. A posteriori corrected images align better, and contain more high-resolution information. Our idea of the correction of the detectors by the data itself is simple, general and elegant. We showed, that it can be applied to images from all fields of digital image processing, including: astronomy, medical imaging and light microscopy.

In Chapter $\mathbf{3}$ we present advanced ideas of movie alignments and implemented an iterative, over-relaxation algorithm for the alignment of full-frame (or sub-frame) cryoEM movie-data. We also introduced a novel "P-spectrum" approach, which we use for assessing the quality of the movie alignments, and which can serve as input for CTFdetermination. Chapters 2 and 3 together demonstrate our improved approaches for initial "pre-processing" of large, single-particle cryo-EM datasets. 
In Chapter $\mathbf{4}$ we focus on the next fundamental step in single-particle cryo-EM: particle picking. Particle picking can introduce serious reference bias if misused. The danger of using external references for the particle picking has been discussed extensively in the recent literature (Henderson 2013, Mao, Castillo-Menendez et al. 2013, Subramaniam 2013, van Heel 2013), where the controversial results by the group of Sodroski (Mao, Wang et al. 2012, Mao, Wang et al. 2013) were challenged. The issue has, however, not yet been resolved formally. We here continue this discussion by analysing the full newly deposited (2015) original dataset. We found further evidences to support our earlier hypothesis that the results of Sodroski and co-workers (Mao, Wang et al. 2012, Mao, Wang et al. 2013) are invalid. This controversy demonstrates the importance of using a clean methodology in single-particle cryo-EM data analysis. We suggest a reliable reference-free approach for particle picking as a solution to avoid reference bias.

Chapter 5 describes our whole reference-free methodology for single-particle cryo-EM data processing. We provided a detailed step-by-step protocol for solving structures of macromolecular complexes with near-atomic resolution. It includes a posteriori camera correction, movie-alignments, CTF-determination of (patches of) micrographs, referencefree particle picking, multivariate statistical eigenvector data compression, alignmentby-classification $(A B C)$, angular reconstitution, and 4D processing. Our methodology is completely reference-free, as opposed to reference-based projection matching approaches, which are prone to reference bias. We demonstrated that our angular reconstitution approach for Euler angles determination is necessarily better and faster than the projection matching. Our extension of the $A B C$ approach to four dimensions (ABC-4D) yields a robust, referencefree pipeline for studying the structure of biological complexes in mixed conformational states.

The power of our approach was illustrated by solving the structure of the giant hemoglobin of Lumbricus terrestris to a near-atomic resolution. We elucidated individual heme group's quasiatomic environment within the heme-binding pocket without crystallographic restraints.

In Chapter $\mathbf{6}$ we performed a single-particle cryo-EM analysis to reveal the structure of the EspB protein, a substrate of the type VII secretion system of Mycobacterium tuberculosis. The dataset we were working with, illustrated challenges in the single-particle cryo-EM. We here confronted a small and heterogeneous dataset which exhibited strong preferred orientations of the sample. These factors precluded us to obtain a near-atomic resolution structure, although we were able to identify two oligomeric states, of the EspB complex: a heptameric and a hexameric one. This study data provides structural insights of the secretion systems of Mycobacterium tuberculosis. 
We expect that single-particle cryo-EM will become an easy and automatic technique for solving protein structures. Already today, due to an ease of the sample preparation and data analysis, many research groups, working with macromolecular complexes using $\mathrm{X}$-ray crystallography techniques, have completely switched to single-particle cryo-EM (Kühlbrandt 2014, Bai, McMullan et al. 2015, Cheng 2015). In the near future we expect a breakthrough in solving a number of unknown structures of small biomolecules and complicated heterogeneous biomolecular complexes. Moreover, we anticipate developments of a number of drugs and vaccines based on the rational structure-based drug design using cryo-EM. We believe our work will contribute significantly to the success of cryo-EM.

\section{REFERENCES}

Bai, X.C., McMullan, G. and Scheres, S.H. (2015) How cryo-EM is revolutionizing structural biology. Trends Biochem Sci 40(1): 49-57.

Cheng, Y. (2015) Single-particle cryo-EM at crystallographic resolution. Cell 161(3): 450-457.

Kühlbrandt, W. (2014) Cryo-EM enters a new era. Elife 3: e03678.

Mao, Y., Castillo-Menendez, L.R. and Sodroski, J.G. (2013a) Reply to Subramaniam, van Heel, and Henderson: Validity of the cryo-electron microscopy structures of the HIV-1 envelope glycoprotein complex. Proceedings of the National Academy of Sciences 110(45): E4178-E4182.

Mao, Y., Wang, L., Gu, C., Herschhorn, A., Desormeaux, A., Finzi, A., Xiang, S.H. and Sodroski, J.G. (2013b) Molecular architecture of the uncleaved HIV-1 envelope glycoprotein trimer. Proc Natl Acad Sci U S A 110(30): 12438-12443.

Mao, Y., Wang, L., Gu, C., Herschhorn, A., Xiang, S.H., Haim, H., Yang, X. and Sodroski, J. (2012) Subunit organization of the membrane-bound HIV-1 envelope glycoprotein trimer. Nat Struct Mol Biol 19(9): 893-899.

Subramaniam, S. (2013) Structure of trimeric HIV-1 envelope glycoproteins. Proc Natl Acad Sci U S A 110(45): E4172-4174.

van Heel, M. (2013) Finding trimeric HIV-1 envelope glycoproteins in random noise. Proc Natl Acad Sci U S A 110(45): E4175-4177. 


\section{SOFTWAREINSTRUMENTATIE VOOR DE STRUKTUURBEPALING VAN BIOL- OGISCHE COMPLEXEN OP QUASI-ATOMAIR NIVEAU MIDDELS CRYOGENE ELECTRONENMIKROSCOPIE Samenvattende discussie}

De introductie van de nieuwe generatie "directe" elektronen detectoren, de invoering van automatische datacollectie, en de ontwikkeling van cryo-EM methodologie over de laatste decennia, maken het nu mogelijk om de structuur van onder andere proteïnecomplexen te bepalen met een quasi atomair oplossend vermogen. De nieuwe detectoren, die ook in "film modus" gebruikt worden (het opdelen van de totale belichting over meerdere "frames"), vereisen nieuwe methodologieën om ook deze grotere en gedetailleerde datasets optimaal te verwerken. We ontwikkelden en testten een breed spectrum aan technieken voor moderne cryo-EM data-analyse. Onze ontwikkelingen, gebaseerd op een filosofie van onbevooroordeelde beeldverweking, vormen een robuuste en snelle strategie om grote cryo-EM datasets te verwerken.

In Hoofdstuk 1 introduceren we de basisprincipes van "single-particle cryo-EM", en diens belang in de structuurbiologie. In het historische overzicht van technische en methodologische ontwikkelingen noemen we belangrijke mijlpalen: van de ontwikkeling van het electromicroscoop door Ernst Ruska en Max Knoll, tot aan de structuren van biologische macromoleculen die met quasi-atomair oplossend vermogen zijn gereconstrueerd. Bij de methodologische ontwikkelingen noemen we de belangrijkste publicaties, die geleid hebben tot de huidige routinematige datacollectie en beeldverwerking. We noemen de belangrijkste factoren die het bereiken van hoge resolutie in de weg staan, en we benadrukken de belangrijkste nieuwe methodes die in deze scriptie worden behandeld. Door de ontwikkelingen in de instrumentatie en de steeds snellere computers, kunnen we ook de originele ideeën in single particle cryo-EM, waarvan sommigen 20-40 jaar oud zijn, verfijnen en beter uitbuiten.

Hoofdstuk 2 illustreert enkele fundamentele voordelen van het werken met grote datasets. We demonstreren dat een grote cryo-EM datasset statistisch significante informatie bevat over de sensor die gebruikt is, deze informatie kan wederom gebruikt worden om de dataset zelf te verbeteren. Onder andere worden vaste patronen weggehaald, die storend kunnen zijn bij de "movie alignment" (het oplijnen van de lichte verschuivingen tussen imdividuele movie frames). Door een succesvolle a posteriori correctie, kunnen betere eindresultaten (met hogere resolutie) worden bereikt. Het concept van het corrigeren van een grote dataset op basis van alleen de data zelf is simpel, algemeen, en elegant. We demonstreerden dat deze techniek toegepast kan worden in velerlei gebieden, onder andere astronomie, medische 
beeldvorming, en lichtmicroscopie.

In Hoofdstuk 3 presenteren we nieuwe ideeën over movie alignment en implementeren we een iteratief over-relaxatiealgoritme voor het oplijnen van gehele beelden (of deelbeelden) in datasets die in film modus zijn opgenomen. We introduceerden een nieuw P-spectrum voor het evalueren van de kwaliteit van zulke oplijningen; P-spectra kunnen ook dienen als invoer voor CTF-bepalingen. Hoofdstukken 2 en 3 samen, demonstreren een verbeterde voorbewerking van grote single-particle cryo-EM datasets.

Hoofdstuk 4 is gericht op een fundamentele stap in het single-particle cryo-EM verwerkingproces: het automatisch vinden van de moleculen in de beelden ("particle picking"). Verkeerd gebruikt kan particle-picking "reference bias" veroorzaken, wat leidt tot het vinden van niet-bestaande informatie. Deze reference-bias problemen hebben recentelijk tot heftige discussies in de literatuur geleid (Mao, Castillo-Menendez et al. 2013, Subramaniam 2013, van Heel 2013). De controversie ontstond over de resultaten van de onderzoeksgroep van Sodroski (Mao, Wang et al. 2012, Mao, Wang et al. 2013). Deze kwestie is echter nog niet formeel de wereld uit. De discussie wordt hier voortgezet in vorm van een analyse van een recentelijk gedeponeerde dataset. De nieuwe analyse ondersteunt onze eerdere hypothese/ conclusie dat de resultaten van Sodroski en collega's (Mao, Wang et al. 2012, Mao, Wang et al. 2013) niet kloppen. De controversie demonstreert het belang van een degelijk onderbouwde methodologie voor de beeldverwerking in single-particle cryo-EM. We stellen een degelijke methodologie voor voor particle picking die geen reference bias vertoont.

Hoofdstuk 5 omschrijft een complete methodologie die reference bias geheel vermijdt. We omschreven stap-voor-stap een protocol voor het verfijnen van structuren van macromoleculaire complexen naar een quasi-atomair oplossend vermogen. Dit protocol omvat de eerdergenoemde a posteriori camera correctie, de oplijning van film-modus data, de CTF-bepaling van de EM-beelden of delen daarvan, een particle picking zonder referenties, multivariate statistische eigenvector datacompressie, "alignment by classification" (ABC), "angular reconstitution", en 4-dimensionale dataverwerking. Onze metholdologie vermijdt bijvoorbeeld de bias die de "projection matching" techniek kan introduceren doordat deze van nature met referenties werkt. Onze uitbereiding van de ABC-techniek naar 4D verwerking (ABC-4D) resulteert in een robuuste, referentieloze pijplijn voor de studie van biologische structuren in heterogene conformaties.

De kracht van onze aanpak wordt geïllustreerd door het oplossen van de structuur van de hemoglobine van Lumbricus terrestris tot quasi-atomaire resolutie. De quasi-atomaire omgeving van een enkele heemgroep dient als voorbeeld van de resolutie die behaald kan 
worden zonder kristallografische beperkingen.

In Hoofdstuk 6 wordt een single-particle cryo-EM analyse toegepast op data van de EspB proteïne, een substraat van type VII afscheidingssysteem van Mycobacterium tuberculosis. Deze dataset illustreert enkele uitdagingen in single-particle cryo-EM. De dataset is relatief klein, en heterogeen, met een sterke voorkeur in de orientaties van de deeltjes. Deze factoren verhinderden het behalen van een quasi-atomaire resolutie. Het was wel mogelijk om twee oligomerische varianten van de EspB multimeer te onderscheiden: een heptamerische en een hexamerische variant. De bestudeerde data geven structurele inzichten op de secretiesystemen van Mycobacterium tuberculosis.

We verwachten dat single-particle cryo-EM een gemakkelijke en automatische techniek kan worden voor het oplossen van proteïnestructuren. Er zijn al meerdere onderzoeksgroepen die historisch gezien macromoleculaire complexen oplossen met behulp van de Röntgenkristallografie, die door de eenvoudigere prepareertechnieken en data-analyse methodes overstappen naar single-particle cryo-EM (Kühlbrandt 2014, Bai, McMullan et al. 2015, Cheng 2015). In de nabije toekomst verwachten we een doorbraak in het oplossen van kleinere biologische complexen en van gecompliceerde heterogene complexen. Bovendien anticiperen we ontwikkelingen van nieuwe medicijnen en vaccins gebaseerd op rationeel medicijnontwerp vanuit de cryo-EM. We denken dat ons werk een belangrijke bijdrage zal leveren tot het succes van single-particle cryo-EM.

\section{REFERENCES}

Bai, X.C., McMullan, G. and Scheres, S.H. (2015) How cryo-EM is revolutionizing structural biology. Trends Biochem Sci 40(1): 49-57.

Cheng, Y. (2015) Single-particle cryo-EM at crystallographic resolution. Cell 161(3): 450-457.

Kühlbrandt, W. (2014) Cryo-EM enters a new era. Elife 3: e03678.

Mao, Y., Castillo-Menendez, L.R. and Sodroski, J.G. (2013a) Reply to Subramaniam, van Heel, and Henderson: Validity of the cryo-electron microscopy structures of the HIV-1 envelope glycoprotein complex. Proceedings of the National Academy of Sciences 110(45): E4178-E4182.

Mao, Y., Wang, L., Gu, C., Herschhorn, A., Desormeaux, A., Finzi, A., Xiang, S.H. and Sodroski, J.G. (2013b) Molecular architecture of the uncleaved HIV-1 envelope glycoprotein trimer. Proc Natl Acad Sci U S A 110(30): 12438-12443.

Mao, Y., Wang, L., Gu, C., Herschhorn, A., Xiang, S.H., Haim, H., Yang, X. and Sodroski, J. (2012) Subunit organization of the membrane-bound HIV-1 envelope glycoprotein trimer. Nat Struct Mol Biol 19(9): 893-899.

Subramaniam, S. (2013) Structure of trimeric HIV-1 envelope glycoproteins. Proc Natl Acad Sci U S A 110(45): E4172-4174.

van Heel, M. (2013) Finding trimeric HIV-1 envelope glycoproteins in random noise. Proc Natl Acad Sci U S A 110(45): E4175-4177. 